\section{An Introduction to the Electronic Theory of} Valency

By Dr. J. C. Speakman. Third edition. Pp. vii + 180. (London: Edward Arnold (Publishers), Ltd., 1955.) 10s. $6 d$. net.

$\mathrm{O}$ UR ever-increasing knowledge of the structure of molecules and of the bonding of the component atoms not only expands the meaning of the term 'valency' but also makes a text-book account of it difficult to write. The second edition of Dr. J. C. Speakman's well-known introduction to the subject was published in 1943, and it is not surprising that he has now drastically revised it. In the new edition, he has changed the word 'modern' of the title to 'electronic' and has divided his work into two parts. The four chapters forming Part 1 deal, at sixth-form level, with the three chief types of bonds, and the treatment is but little changed from that in the second edition.

Part 2, however, he has almost completely rewritten. In a new chapter (5), without the use of any mathematics, Dr. Speakman has essayed to expound, in what he calls "a pictorial and descriptive way", the molecular configuration of electrons both from the valency-bond and from the molecular-orbital approach. The titles of Chapters 6-11 remain unchanged, but the subject-matter has been rewritten from the modern point of view. The hydrogen bond now gets six pages. Chapter 12 contains an interesting discussion of the meaning of the term valency and of the present-day position of the concept.

Throughout Part 2 Dr. Speakman, while admitting difficulties, apparent contradictions and conflicting views, is temperately critical and nowhere dogmatic. Implicit in his attitude to the subject is the advice to accept approaches to truth for their usefulness and not to let ideas on valency crystallize. His book is a praiseworthy attempt to give a simplified account of the present-day position of this concept.

G. Fowles

\section{Annuaire pour l'An 1956}

Publié par le Bureau des Longitudes, avec un Supplément pour l'An 1957. Pp. viii + 729. (Paris: Gauthier-Villars, 1956.) n.p.

Trit "HE "Annuaire" for 1956 of the Bureau des Longitudes, together with a supplement for the year 1957, consists of tables, definitions and articles contained on 614 principal and 121 supplementary pages, and several additional folding diagrams illustrative of the text.

The Bureau des Longitudes, constituted on June 25, 1795, by the then French National Convention, consists of fourteen members and six additional members, all of them French nationals, together with thirty internationally distinguished correspondents, not necessarily of French nationality (three are British). It is charged with making recommendations for the improvement of the different branches of astronomy and their application to geography, navigation and the physies of the Earth, and it is responsible for five other regular publications in addition to the "Annuaire".

The present "Annuaire" covers the following subjects: calendars - the principal world calendars and astronomical data associated with them, and tides; geophysics - the data of meteorological, atmospheric electricity and teirestrial magnetic phenomena; time-astronomical data concerning the Sun, Moon, major planets, comets and certain stars ; tables of weights and measures ; and physical and chemical constants. The articles are "Radioélectricité et opérations mondiales des longitudes", by B. Decaux, and "Les récepteurs photoélectriques", by $A$. Lallemand.

\section{A Short History of Medicine}

By Prof. Erwin H. Ackerknecht. Pp. xviii +258 . (New York: The Ronald Press Company, 1955.) 4.50 dollars.

R. ACKERKNECH'T, an accomplished scholar, is professor of the history of medicine in the University of Wisconsin. He has here set himself to provide medical practitioners with a short and simple account of the development of their art and has succeeded admirably. The work is concise and wel! balanced; but perhaps its most outstanding feature is the exceptional skill shown in treating the very intricate developments of the first half of the twentieth century-precisely the period where most such short histories tend to fail. This last chapter is so well done that many practitioners will find the volume a useful reference desk-book which they may conveniently consult for the dates, circumstances and authors of the main modern treatments and remedies. The historical perspective is well maintained throughout though, in my opinion, later editions would gain by condensing or telescoping the pre-Greek medical systems. 'J'hese are of great interest and are well treated; but their bearing on scientific medicine is too remote to appeal to the audience for which this book is so particularly well designed. Further space might be saved on illustrations, the selection and reproduction of which show less of the caro lavished on tho text. These are minor and easily reparable faults in a work which I would heartily recommend.

Charles Singer

\section{Stratigraphic Geology}

By Maurice Gignoux. English translation from the Fourth French Edition, 1950, by Gwendolyn G. Woodford. (Series of Geology Texts.) Pp. xvi+682. (San Francisco: W. H. Freeman and Company ; London: Bailey Bros. and Swinfen, Ltd., 1955.) 9.50 dollars ; $80 s$.

TCHE "Géologie stratigraphique" of Maurice

Gignoux has been justly famous as an excellent exposition of stratigraphy as seen from the French point of view. Now that its fourth edition has been translated, it has become available to those who prefer to read it in English. The book has not changed its character as a result of G. G. Woodford's successful effort (translations of this kind are notoriously difficult); it has remained intensely French. There is the elegant and didactically effective method of dealing with typical areas in detail, leaving the rest of the world to a generalized treatment. Most examples have been taken from France, and the Alps have received special attention. Herein lies the chief value of the book for the English-speaking reader.

Similarly, references are particularly numerous for France and French territories, especially North Africa. In this edition, the questions of the Sahelian and of the Nummulitic formations of Egypt, Tunisia and Algeria have received careful attention. On the other hand, non-French Continental and British publications have been considered in a very uneven manner, but this is excusable in a work of worldwide scope.
F. E. ZEUNER 